\title{
PROPOSED SUPPRESSION UNDER THE PLENARY POWERS OF THE GENERIC NAME “IPHIS"' MEIGEN, 1800, FOR THE PURPOSE OF VALIDATING THE GENERIC NAME “IPHIS " LEACH, 1817 (CLASS CRUSTACEA, ORDER DECAPODA) (PROPOSED CORRECTION OF AN ERROR IN “ OPINION" 73)
}

\section{By FRANCIS HEMMING, C.M.G., C.B.E., Secretary to the International Commission on Zoological Nomenclature}

(Commission's reference : Z.N.(S.) 562)

The purpose of the present application is to seek the assistance of the International Commission in rectifying an error in the Official List of Generic Names in Zoology in connection with the entry thereon of the generic name Iphis Leach, 1817 (Zool. Miscell. 3 : 25) made by the Ruling given in Opinion 73 (1922, Smithson. misc. Coll. 73 (No. 1) : 23-31). The above genus is monotypical with Cancer septemspinosus Fabricius, 1787 (Mantissa Ins. 1 : 325) as type species.

2. The error in Opinion 73 with which the present application is concerned came to light in 1944 in the course of a preliminary survey which I then made of the entries on the Official List made in the pre-1936 Opinions. I then discovered that the name Iphis Leach, 1817, is invalid by reason of being a junior homonym of the name Iphis Meigen, 1800 (Nouv. Class. Mouches deux Ailes : 27) (Class Insecta, Order Diptera). The fact that this has passed unnoticed by workers in the Crustacea is due no doubt to the fact that the pamphlet in which the name Iphis Meigen was published was completely ignored for more than a hundred years after its publication.

3. In a case of this kind clearly the first step to be taken is to ascertain whether the older name is in use in the group concerned and therefore whether any disturbance or other inconvenience would be suffered by workers in that group if the name in question were to be suppressed by the Commission under its Plenary Powers. In the present instance I applied for advice to Dr. Alan Stone (U.S. Department of Agriculture, Agricultural Research Administration, Bureau of Entomology and Plant Quarantine, Washington, D.C., U.S.A.), who in a letter dated 16th February 1944 informed me :-

(1) that the type species of Iphis Meigen, 1800, is Musca ungulata Linnaeus, 1758 (Syst. Nat. (ed. 10) $1: 598$ ) by selection by Coquillet (1910, Proc. U.S. nat. Mus. $37: 555)$;

(2) that the nominal species Musca ungulata Linnaeus, 1758 , is also the type species of the genus Dolichopus Latreille, 1796 (Précis caract. gén. Ins. : 159) by selection by Latreille, 1810 (Consid. gén. Anim. Crust. Arach. Ins. : 443, 387); 
(3) that in view of (1) and (2) above, the generic name Iphis Meigen, 1800, is a junior objective synonym of Dolichopus Latreille, 1796.

4. In my view the information supplied by Dr. Stone clears the ground for the validation of the generic name Iphis Leach, 1817, by the suppression under the Plenary Powers of the unwanted-because objectively invalidname Iphis Meigen, 1800, in the Order Diptera. I accordingly recommend that this action should be taken.

5. Under the General Directive given by the International Congress of Zoology that in rendering Opinions the Commission is to cover the whole field involved, it will be necessary in any decision on the present case also to place on the Official List of Generic Names in Zoology the generic name Dolichopus Latreille, 1796, and on the Official List of Specific Names in Zoology the name ungulata Linnaeus, 1758, as published in the combination Musca ungulata (specific name of type species of Dolichopus Latreille, 1796). At the same time it will be necessary to place on the Official Index of Rejected and Invalid Generic Names in Zoology certain names which are junior homonyms of the generic names dealt with in the present application.

6. The nominal genus Iphis Leach, 1817 (Class Crustacea) is, I am informed by Dr. Isobel Gordon (British Museum (Natural History), London), currently referred to the family LEUCOSIIDAE, and in consequence no family-group-name question arises in this case.

7. I am indebted to Dr. John Smart (University of Cambridge, Department of Zoology, Cambridge) for information regarding the family-group names based on the generic name Dolichopus Latreille, 1796. Samouelle (1819, Entomologist's useful Compendium : 294) was the first author who has been traced as having used a "-DAE" termination, but he made two spelling mistakes, the name appearing in his book as DOLYCHOPODAE. Moreover, Samouelle attributed this name to Leach, without giving a bibliographical reference. Possibly, it was only used by Leach in manuscript.

8. The recommendations which I now submit are that the International Commission should :-

(1) use its Plenary Powers for the purpose of suppressing the generic name Iphis Meigen, 1800 (Class Insecta, Order Diptera), for the purposes both of the Law of Priority and of the Law of Homonymy ;

(2) substitute the following revised entry on the Official List of Generic Names in Zoology for Name No. 160 :-

Iphis Leach, 1817, Zool. Miscell. $3: 25$ (gender : masculine) (type species, by monotypy: Cancer septemspinosus Fabricius, 1787 (Mantissa Ins. $1: 325)$ ); 
(3) place the under-mentioned generic name on the Official List of Generic Names in Zoology :-

Dolichopus Latreille, 1796 (gender: masculine) (type species, by selection by Latreille (1810) : Musca ungulata Linnaeus, 1758);

(4) place the under-mentioned specific names on the Official List of Specific Names in Zoology :-

(a) septemspinosus Fabricius, 1787, as published in the combination Cancer septemspinosus (specific name of type species of Iphis Leach, 1817) ;

(b) ungulata Linnaeus, 1758 , as published in the combination Musca ungulata (specific name of type species of Dolichopus Latreille, 1796);

(5) place the under-mentioned generic names on the Official Index of Rejected and Invalid Generic Names in Zoology :-

(a) Dolichopus Van der Hoeven, [1856], Handb. Zool. 2 : 422, 431 (a junior homonym of Dolichopus Latreille, 1796);

(b) Iphis Meigen, 1800, as suppressed under the Plenary Powers under (1) above ;

(c) the under-mentioned names which are junior homonyms of Iphis Leach, 1817 :-

(i) Iphis Koch, 1835, Deutschl. Crust. (Heft 2) : Tab. 6

(ii) Iphis Laporte, 1836, Rev. Entom. 4(1) : 7 .

(6) place the under-mentioned family-group name on the Official List of Family-Group Names in Zoology:-DOLICHOPIDAE (correction of DoLICHOPIDEs) Latreille, 1807, Gen. Crust. Ins. 3 : 290 (type genus : Dolichopus Latreille, 1796).

(7) place the under-mentioned family-group names on the Official Index of Rejected and Invalid Family-Group Names in Zoology :-

(a) DOLICHOPIDEs Latreille, 1807 (type genus : Dolichopus Latreille, 1897) (an Invalid Original Spelling for DOLICHOPIDAE) ;

(b) DOLYCHOPODAE Samouelle, 1819 (type genus Dolichopus (misspelt Dolychopus by Samouelle) Latreille, 1796) (an Erroneous Subsequent Spelling for DOLICHOPIDAE). 


\section{$2 \mathrm{BHL}$ Biodiversity Heritage Library}

Hemming, Francis. 1955. "Proposed suppression under the plenary powers of the generic name Iphis Meigen, 1800, for the purpose of validating the generic name Iphis Leach, 1817 (Class Crustacea, Order Decapoda) (Proposed correction of an error in Opinion 73)." The Bulletin of zoological nomenclature 11, 79-81. https://doi.org/10.5962/bhl.part.2821.

View This Item Online: https://www.biodiversitylibrary.org/item/44292

DOI: https://doi.org/10.5962/bhl.part.2821

Permalink: https://www.biodiversitylibrary.org/partpdf/2821

\section{Holding Institution}

Natural History Museum Library, London

\section{Sponsored by}

Natural History Museum Library, London

\section{Copyright \& Reuse}

Copyright Status: In copyright. Digitized with the permission of the rights holder.

License: http://creativecommons.org/licenses/by-nc-sa/3.0/

Rights: https://biodiversitylibrary.org/permissions

This document was created from content at the Biodiversity Heritage Library, the world's largest open access digital library for biodiversity literature and archives. Visit BHL at https://www.biodiversitylibrary.org. 